\title{
MENAKAR PARADIGMA KEAMANAN NASIONAL MELALUI ANALISIS ISI TERHADAP UNDANG-UNDANG No. 17 TAHUN 2011 TENTANG INTELIJEN NEGARA
}

\author{
Surwandono \\ Ketua Program Magister Hubungan Internasional Universitas Muhammadiyah \\ Yogyakarta \\ (wsurwandono@yahoo.com) \\ Ratih Herningtyas \\ Universitas Muhammadiyah Yogyakarta \\ (ratih.herningtyas@gmail.com) \\ Dian Nursita \\ Universitas Muhammadiyah Yogyakarta \\ (rdiannursita@gmail.com)
}

\begin{abstract}
Abstrak
Pelaksanaan serta kelembagaan intelijen di Indonesia telah mengalami sejumlah perubahan seiring dengan dinamika politik domestik serta perkembangan isu keamanan yang terjadi baik di dalam maupun luar negeri. Reformasi intelijen di Indonesia ditandai dengan pembentukan Badan Intelijen Negara atau BIN serta lahirnya Undang-Undang Nomor 17 Tahun 2011 Tentang Intelijen Negara. Tulisan ini bertujuan untuk menganalisa paradigma yang digunakan dalam menentukan arah kebijakan kemanan di Indonesia dalam Undang-Undang Nomor 17 tahun 2011 dengan menggunakan metode content analysis. Analisa terhadap indikator yang mewakili tiga paradigma; realisme, liberalism, dan konstruktivisme menunjukkan bahwa Undang-Undang Intelijen Negara sangat dipengaruhi oleh paradigm realisme. Kata Kunci: Intelijen, Keamanan, Paradigma, Realisme, UU Nomor 17 Tahun 2011.

Abstract

The evolution of both domestic and international security issues have influenced the development of Indonesia intelligence and its agencies. Indonesia intelligence reform is marked by the establishment of Badan Intelijen Nasional or Indonesia National Intelligence Agency and the enactment of Law Number 17 of 2011 on The State Intelligence. In order to reveal the paradigm used in determining the direction of Indonesia's national security policy, this paper analyzes Law Number 17 of 2011 on The State Intelligence using content analysis method. Analysis among indicators representing three paradigms; realism, liberalism, and constructivism shows that Law Number 17 of 2011 on The State Intelligence is strongly influenced by realist paradigm.
\end{abstract}

Keywords: Intelligence, Law Number 17 of 2011, National Security, Paradigm,Realism. 
Pendahuluan

Indonesia kini dihadapkan dengan sejumlah problem keamanan dalam negeri. Sejumlah problem di antaranya terorisme, konflik sosialagama, cyber crime, perang opini melalui berita dan sosial media, serta gerakan separatisme masih mewarnai persoalan keamanan di Indonesia. Indeks perdamaian di Indonesia pada pada tahun 2017 menunjukkan adanya penurunan yang signifikan di antara 18 negara lainnya di wilayah AsiaPasifik. Indonesia yang awalnya berada di peringkat ke-42 pada tahun 2016, kemudian turun menjadi peringkat ke-52 pada tahun 2017. Penurunan tersebut salah satunya disebabkan oleh tingkat teror politik di Indonesia pada tahun 2017 mencapai angka 3,5 dari 5; berdasarkan peningkatan jumlah tahanan politik, maupun penahanan atas dasar politik yang baru saja terjadi, eksekusi atau pembunuhan karena alasan politik, penahanan tanpa proses pengadilan, serta sejumlah pelanggaran HAM (IEP, 2017).

\section{Penanggulangan terhadap} problem keamanan nasional tentunya tidak dapat dipisahkan dari adanya aktivitas intelijen. Intelijen merupakan aspek yang sangat menentukan keselamatan negara dari berbagai ancaman, tantangan, hambatan, dan gangguan baik yang berasal dari dalam maupun luar negeri (Saronto \& Karwita, 2012). Intelijen secara umum dapat dimaknai sebagai informasi yang terkait dengan suatu entitas asing; yaitu entitas yang seringkali dianggap sebagai sebuah ancaman atau lawan, maupun lembaga yang berkaitan dengan pengumpulan informasi tersebut (Lerner \& Lerner, 2004).

Dalam fenomena pasang surut intelijen di Indonesia, praktek intelijen di Indonesia mulai dikenal secara meluas semenjak tahun 1960-an, ketika pemerintah pusat membentuk Badan Pusat Intelijen atau BPI yang hampir bersamaan dengan lahirnya Undang-Undang Nomor 11/PNPS/1963 Tentang Pemberantasan Kegiatan Subversi (Kunarto, 1999) ; tindakan yang memutarbalikkan, merongrong, atau menyelewengkan ideologi Pancasila atau haluan negara; menggulingkan, merusak, atau merongrong kekuasaan negara atau kewibawaan pemerintah yang sah atau aparatur negara; dan menyebarkan rasa permusuhan atau menimbulkan permusuhan, perpecahan, pertentangan, kekacauan, kegoncangan, atau kegelisahan di masyarakat (Penetapan Presiden 
No.11 Tahun 1963 Tentang

Pemberantasan Kegiatan Subversi, 1963). UU Anti-Subversi kemudian dicabut pada tahun 1999 karena dianggap menjadi penyebab sejumlah pelanggaran HAM yang terjadi selama masa Orde Baru Indonesia, salah satunya adalah mengenai hak rakyat untuk berserikat dan berkumpul serta menyampaikan aspirasinya, sesuai yang termaktub dalam pasal 28E UUD 1945.

Pelaksanaan intelijen pada beberapa dekade berikutnya mengalami perubahan seiring dengan dinamika politik domestik serta perkembangan isu keamanan yang terjadi baik di dalam maupun luar negeri. Peristiwa reformasi pada tahun 1998 tidak hanya berimplikasi kepada perubahan dalam pemerintahan, namun juga perubahan dalam lembaga intelijen di Indonesia. Reformasi lembaga intelijen Indonesia bertujuan untuk meningkatkan profesionalisme, serta mengubah persepsi mengenai pemerintah pada Era Orde Baru sering diidentikan sebagai negara intelijen. Badan Kordinasi Intelijen Negara atau BAKIN yang terbentuk sejak Orde Baru kemudian berubah menjadi Badan Intelijen Negara atau BIN pada tahun 2000. BIN kemudian menjadi koordinator bagi badan-badan intelijen yang ada di berbagai lembaga negara, seperti Intelijen TNI, Intelijen Kepolisian, Intelijen Kejaksaan dan Intelijen Kementerian/lembaga pemerintah non-Kementerian (BIN, 2017).

Hingga saat ini, lembagalembaga intelijen negara telah menangani sejumlah problem keamanan; di antaranya pemberantasan terhadap tindak pidana terorisme, narkoba, pelarian kriminal, pemetaan terhadap konflik sosial, maupun problem yang terkait dengan pertahanan seperti separatisme yang dilakukan oleh GAM dan OPM, serta isu perbatasan. Walaupun lembagalembaga intelijen telah banyak memberikan kontribusi, namun regulasi yang mengatur tentang intelijen; UU No.17 Tahun 2011, baru disahkan satu dekade setelah pembentukan BIN. BIN saat ini juga berhadapan dengan sejumlah tantangan, baik yang terkait dengan problem keamanan nasional, maupun perbaikan dalam badan serta pelaksanaan tugas intelijen itu sendiri.

Fenomena konflik dan perdamaian yang terjadi dalam sejarah umat manusia telah melahirkan beragam pendekatan dalam memandang isu keamanan. Realisme merupakan pendekatan yang banyak 
berkontribusi dalam studi tentang keamanan. Adanya security dilemma mempengaruhi gagasan pendekatan realisme yang memandang bahwa kapasitas militer merupakan hal utama yang diperlukan untuk menjaga kedaulatan negara (Baylis, 2005). Gagasan bahwa negara merupakan entitas tertinggi menyebabkan realisme dikatakan sebagai pendekatan yang sangat state-centric. Berbeda dengan realisme, gagasan liberalisme terutama bagi kalangan idealis. Liberalis melihat bahwa kondisi perdamaian hanya bisa dicapai pemerintahan yang berbasis kerakyatan, representatif yang demokratis, penekanan terhadap kerjasama, serta komitmen terhadap hak asasi manusia (Baylis, 2005)

Fenomena globalisasi, pesatnya arus informasi, serta kemajuan teknologi telah melahirkan pendekatan yang lebih interpretatif dan reflektif dalam memandang isu keamanan, yaitu konstruktivisme. Konstruktivis lebih banyak mengaitkan persoalan keamanan dengan faktor ide dan norma dibandingkan dengan kekuasaan politik dan militer (William, 2008). Bagi konstruktivis, dilema keamanan bukanlah sebuah gifted issue, namun hasil dari konstruksi sosial, sehingga problem keamanan dapat diatasi melalui sharing ideas di antara para aktor; baik aktor negara maupun sipil.

Ketiga pendekatan di atas telah mempengaruhi cara pandang sejumlah negara dalam menentukan arah kebijakan dalam tata kelola keamanan. Sejumlah problematika keamanan yang terjadi di Indonesia serta signifikansi lembaga intelijen sebagai aktor yang berperan penting dalam menjaga keamanan negara, menjadikan pembahasan mengenai pendekatan dalam keamanan di Indonesia menarik untuk dikaji. Maka dari itu, penelitian ini bermaksud untuk mengidentifikasi teori serta pendekatan yang digunakan dalam pengaturan tata kelola keamanan di Indonesia yang terkandung dalam UU No.17 tahun 2011.

\section{METODE PENELITIAN}

Penelitian ini menggunakan metode penelitian kuantitatif, yaitu dengan mengukur pesan spesifik atau signs yang terkandung dalam UU No. 17 tahun 2011 Tentang Intelijen Negara beserta penjelasannya. Terdapat lima indikator yang digunakan dalam pengukuran, yaitu aktor, otoritas, anggaran, tata kelola, dan ouput. Sejumlah kata, frasa, kalimat, maupun simbol spesifik yang merepresentasikan lima indikator 
dalam tata kelola keamanan di Indonesia kemudian diklasifikasikan ke dalam tiga kelompok pendekatan, yaitu realisme, liberalisme, dan konstruktivisme. Pengukuran terhadap jumlah penggunaan kata ditabulasikan untuk kemudian dianalisa.

Untuk menganalisa hasil pengukuran tersebut, peneliti telah menyusun tiga hipotesa: pertama, pengaturan terhadap tata kelola keamanan Indonesia menggunakan pendekatan realisme, kedua, pengaturan tata kelola keamanan Indonesia menggunakan pendekatan liberalisme, dan ketiga, pengaturan tata kelola keamanan Indonesia menggunakan pendekatan konstruktivisme.

\section{ANALISA TERHADAP UU NO 11 TAHUN 2017 TENTANG INTELIJEN NEGARA}

Dalam rangka menjamin terlaksananya tujuan negara, sesuai yang tertulis dalam pembukaan UUD 1945, yaitu melindungi segenap bangsa Indonesia dan seluruh tumpah darah Indonesia, serta evolusi konsep keamanan yang kini memiliki spektrum yang lebih luas, serta memberikan kepastian hukum terhadap penyelenggaraan intelijen di Indonesia yang telah berlangsung sejak lama. Pada tanggal 7 November
2011, pemerintah mengesahkan UU. No 17 tahun 2011 sebagai instrumen yang meregulasi pelaksanaan intelijen di Indonesia.

Dalam undang-undang, intelijen didefinisikan sebagai pengetahuan, organisasi, serta kegiatan yang terkait dengan perumusan kebijakan, strategi nasional, dan pengambilan keputusan berdasarkan analisis dari informasi dan fakta yang dikumpulkan melalui metode kerja untuk mendeteksi dan memberikan peringatan dini dalam rangka mencegah, menangkal dan menanggulangi setiap ancaman terhadap keamanan nasional (UndangUndang Nomor 17 Tahun 2011 Tentang Intelijen, 2011). Aktivitas intelijen dilaksanakan oleh personel intelijen yang merupakan warga negara Indonesia yang memiliki kemampuan khusus Intelijen dan mengabdikan diri dalam dinas Intelijen Negara.

Terdapat lima indikator yang digunakan dalam menganalisa pendekatan yang digunakan dalam UU No.17 Tahun 2011, yaitu aktor, otoritas, anggaran, tata kelola, serta output atau luaran yang hendak dicapai. Hasil analisa pada Tabel 1 menunjukkan bahwa UU No.17 Tahun 2011 lebih banyak mengedepankan 
peran negara dalam aktivitas intelijen dibandingkan dengan aktor-aktor non negara; korporasi, individu, lembaga, maupun organisasi internasional. Hasil menunjukkan bahwa persentase aktoraktor realis lebih tinggi dibandingkan dengan aktor-aktor liberalis dan konstruktivis; aktor-aktor realis sebesar $90,37 \%$ sedangkan liberalis $8,89 \%$ dan konstruktivis hanya $0,74 \%$. Tingginya penggunaan kata dan frasa negara diikuti dengan sejumlah lembaga negara lainnya seperti kepolisian, militer, Badan Intelijen Negara, Kepolisian, Tentara Nasional Indonesia atau TNI, kejaksaan, serta pejabat pemerintahan. Di samping itu, aktivitas intelijen di Indonesia lebih mengarah kepada isu keamanan nasional dibandingkan dengan isu strategis atau pertahanan. Hal tersebut dapat dilihat dari jumlah penggunaan kata maupun frasa kepolisian yang lebih tinggi dibandingkan dengan TNI.

Tabel 1. Hasil Pengukuran Indikator Aktor dalam UU No. 17 Tahun 2011

\begin{tabular}{|c|c|c|c|}
\hline $\begin{array}{c}\text { Pendek } \\
\text { at } \\
\text { An }\end{array}$ & $\begin{array}{l}\mathbf{N} \\
\mathbf{O}\end{array}$ & Aktor & $\begin{array}{l}\text { Jumla } \\
\text { h kata }\end{array}$ \\
\hline \multirow{5}{*}{$\begin{array}{c}\text { Realis } \\
\text { me }\end{array}$} & 1 & Negara & 194 \\
\hline & 2 & Kepolisian & 6 \\
\hline & 3 & $\begin{array}{c}\text { Tentara } \\
\text { Nasional } \\
\text { Indonesia } \\
\text { (TNI) }\end{array}$ & 3 \\
\hline & 4 & Kejaksaan & 3 \\
\hline & 5 & Pejabat & 2 \\
\hline
\end{tabular}

\begin{tabular}{|c|c|c|c|}
\hline & 6 & $\begin{array}{c}\text { Badan } \\
\text { Intelijen }\end{array}$ & 36 \\
\hline & 7 & $\begin{array}{l}\text { Negara } \\
\text { Asing }\end{array}$ & 0 \\
\hline & 8 & $\begin{array}{c}\text { Badan } \\
\text { Pertahanan } \\
\text { Nasional }\end{array}$ & 0 \\
\hline & 9 & $\begin{array}{c}\text { Badan } \\
\text { Nasional } \\
\text { Penanggulan } \\
\text { gan } \\
\text { Terorisme }\end{array}$ & 0 \\
\hline & 10 & $\begin{array}{c}\text { Pusat } \\
\text { Pelaporan } \\
\text { dan Analisis } \\
\text { Transaksi } \\
\text { Keuangan } \\
\text { PPATK) }\end{array}$ & 0 \\
\hline & & TOTAL & 244 \\
\hline & & $\begin{array}{c}\text { PERSENTA } \\
\text { SE }\end{array}$ & $\begin{array}{c}90.37 \\
\%\end{array}$ \\
\hline \multirow{6}{*}{$\begin{array}{l}\text { Liberal } \\
\text { isme }\end{array}$} & 11 & Korporasi & 0 \\
\hline & 12 & $\begin{array}{c}\text { Orang/indivi } \\
\mathrm{du}\end{array}$ & 17 \\
\hline & 13 & $\begin{array}{l}\text { Badan } \\
\text { Hukum }\end{array}$ & 2 \\
\hline & 14 & Perusahaan & 5 \\
\hline & & TOTAL & 24 \\
\hline & & $\begin{array}{c}\text { PERSENTA } \\
\text { SE }\end{array}$ & $\begin{array}{c}8.89 \\
\%\end{array}$ \\
\hline \multirow{6}{*}{$\begin{array}{c}\text { Konstr } \\
\text { uk } \\
\text { tivisme }\end{array}$} & 16 & $\begin{array}{c}\text { Lembaga } \\
\text { Asing } \\
\end{array}$ & 2 \\
\hline & 17 & $\begin{array}{l}\text { Yurisdiksi } \\
\text { Asing }\end{array}$ & 0 \\
\hline & 18 & $\begin{array}{c}\text { Perjanjian } \\
\text { Internasional }\end{array}$ & 0 \\
\hline & 19 & $\begin{array}{c}\text { Organisasi } \\
\text { Internasional }\end{array}$ & 0 \\
\hline & & TOTAL & 2 \\
\hline & & $\begin{array}{c}\text { PERSENTA } \\
\text { SE }\end{array}$ & $\begin{array}{c}0.74 \\
\%\end{array}$ \\
\hline \multicolumn{3}{|c|}{ TAL AKTOR } & 270 \\
\hline
\end{tabular}

Analisa terhadap kewenangan yang terkait dengan penyelenggaraan intelijen, menunjukkan bahwa otoritas 
yang diatur dalam UU No.17 Tahun 2011 juga mengarah kepada pendekatan realisme dengan persentase $93,46 \%$, di antaranya otoritas untuk melaksanakan pelindungan, penyadapan, penggalian informasi, pengawasan, koordinasi dengan badan intelijen lainnya, pendeteksian ancaman, serta sejumlah tindakan lainnya yang menjadi kewenangan bagi negara. Sedangkan kata yang mewakili pendekatan konstruktivis sangat sedikit.

Undang-undang menjamin perlindungan terhadap kerahasiaan informasi serta personel intelijen. Badan Intelijen Negara sebagai lembaga intelijen pusat berwenang untuk mengkoordinasi sejumlah badan intelijen seperti kepolisian, militer, kejaksaan, maupun lembaga negara lainnya. Selain itu, berbeda dengan pandangan liberalis yang sangat mengedepankan persoalan privasi, UU No.17 Tahun 2011 juga mengakomodasi aktivitas surveillance melalui penyadapan, pemeriksaan aliran keuangan, serta penggalian informasi terhadap sejumlah kegiatan yang mengancam keamanan nasional, seperti terorisme, separatism, spionase, serta sabotase.
Tabel 2. Hasil Pengukuran Indikator Otoritas dalam UU No. 17 Tahun 2011

\begin{tabular}{|c|c|c|c|}
\hline $\begin{array}{c}\text { Pende } \\
\text { ka } \\
\text { tan }\end{array}$ & $\begin{array}{l}\mathbf{N} \\
\mathbf{O}\end{array}$ & Otoritas & $\begin{array}{c}\text { Jumlah } \\
\text { kata }\end{array}$ \\
\hline \multirow{18}{*}{$\begin{array}{l}\text { Real } \\
\text { isme }\end{array}$} & 1 & $\begin{array}{c}\text { Koordinasi } \\
\text { intelijen }\end{array}$ & 10 \\
\hline & 2 & $\begin{array}{l}\text { Peringatan } \\
\text { dini }\end{array}$ & 7 \\
\hline & 3 & Rehabilitasi & 2 \\
\hline & 4 & Pengadilan & 7 \\
\hline & 5 & $\begin{array}{c}\text { Penangkala } \\
n\end{array}$ & 4 \\
\hline & 6 & $\begin{array}{c}\text { Pendeteksia } \\
n\end{array}$ & 7 \\
\hline & 7 & Penindakan & 0 \\
\hline & 8 & $\begin{array}{c}\text { Penangkapa } \\
n\end{array}$ & 1 \\
\hline & 9 & $\begin{array}{c}\text { Penyimpan } \\
\text { an }\end{array}$ & 1 \\
\hline & 10 & $\begin{array}{c}\text { Pelindunga } \\
n\end{array}$ & 17 \\
\hline & 12 & Pengkajian & 1 \\
\hline & 13 & Penyadapan & 11 \\
\hline & 14 & $\begin{array}{c}\text { Pemeriksaa } \\
\text { n }\end{array}$ & 7 \\
\hline & 15 & $\begin{array}{c}\text { Penggalian } \\
\text { informasi }\end{array}$ & 11 \\
\hline & 16 & $\begin{array}{l}\text { Perekrutan } \\
\text { intel }\end{array}$ & 4 \\
\hline & 17 & $\begin{array}{c}\text { Pengawasa } \\
n\end{array}$ & 10 \\
\hline & & TOTAL & 100 \\
\hline & & $\begin{array}{c}\text { PERSENT } \\
\text { ASE }\end{array}$ & $93.46 \%$ \\
\hline \multirow{4}{*}{$\begin{array}{c}\text { Konstr } \\
\text { uk } \\
\text { tivism } \\
\text { e }\end{array}$} & 18 & Pencegahan & 5 \\
\hline & 19 & $\begin{array}{c}\text { Penanggula } \\
\text { ngan }\end{array}$ & 2 \\
\hline & & TOTAL & 7 \\
\hline & & $\begin{array}{c}\text { PERSENT } \\
\text { ASE }\end{array}$ & $6.54 \%$ \\
\hline \multicolumn{3}{|c|}{ TOTAL OTORITAS } & 107 \\
\hline
\end{tabular}

Pengukuran terhadap sumber anggaran menunjukkan bahwa 
pelaksanaan intelijen negara sepenuhnya bergantung kepada negara. Sesuai yang diatur dalam BAB VIII Tentang Pembiayaan, Pertanggungjawaban dan Pengawasan, dalam Pasal 41 Tentang Pembiayaan tertulis bahwa "Biaya yang diperlukan untuk penyelenggaraan Intelijen Negara dibebankan pada Anggaran Pendapatan dan Belanja Negara". Tidak terdapat keterangan bahwa pelaksanaan intelijen dibantu atau didanai oleh negara lain (asing), lembaga-lembaga lain di luar pemerintah, maupun masyarakat.

Tabel 3. Hasil Pengukuran Indikator Anggaran dalam UU No. 17 Tahun 2011

\begin{tabular}{|c|c|c|c|}
\hline $\begin{array}{c}\text { Pende } \\
\text { kat } \\
\text { An }\end{array}$ & $\begin{array}{l}\mathbf{N} \\
\mathbf{O}\end{array}$ & $\begin{array}{l}\text { Sumber } \\
\text { Anggaran }\end{array}$ & $\begin{array}{c}\text { Jumlah } \\
\text { kata }\end{array}$ \\
\hline \multirow{5}{*}{$\begin{array}{l}\text { Realis } \\
\text { me }\end{array}$} & 1 & Pemerintah & 0 \\
\hline & 2 & Lembaga & 0 \\
\hline & 3 & APBN & 1 \\
\hline & & TOTAL & 1 \\
\hline & & $\begin{array}{l}\text { PERSENTA } \\
\text { SE }\end{array}$ & $100.00 \%$ \\
\hline \multirow{3}{*}{$\begin{array}{c}\text { Konst } \\
\text { ruk } \\
\text { Tivis } \\
\text { me } \\
\end{array}$} & 4 & Masyarakat & 0 \\
\hline & & TOTAL & $\mathbf{0}$ \\
\hline & & $\begin{array}{c}\text { PERSENTA } \\
\text { SE } \\
\end{array}$ & $0.00 \%$ \\
\hline \multicolumn{3}{|c|}{$\begin{array}{ll}\text { TOTAL } & \text { KATA } \\
\text { ANGGARAN } & \end{array}$} & 1 \\
\hline
\end{tabular}

Tata kelola keamanan dalam UU Intelijen menunjukkan peningkatan jumlah penggunaan kata dan frasa yang mewakili pendekatan liberalisme; jaminan terhadap informasi, penghormatan terhadap kode etik, dan Hak Asasi Manusia, serta kata dan frasa konstruktivisme; penghormatan terhadap nilai-nilai demokrasi, serta agama. Walaupun demikian, jumlah penggunaan kata dan frasa di antaranya, kerahasiaan, ancaman, peraturan mengindikasikan penggunaan paradigma realisme dalam penyusunan undang-undang tetap lebih tinggi. Di samping itu, pada bagian penjelasan undangundang, tertulis bahwa penghormatan terhadap HAM serta kebebasan harus dibatasi dan diatur dengan perundangundangan. Seperti yang dijamin dalam Pasal 28J UUD 1945 bahwa setiap orang wajib menghormati hak asasi manusia orang lain dalam tertib kehidupan bermasyarakat, berbangsa, dan bernegara.

Kerahasiaan merupakan salah satu asas dari penyelenggaraan intelijen. Kewajiban intelijen untuk melindungi rahasia, klasifikasi rahasia intelijen, serta masa retensi diatur dalam UU Intelijen. Kata ancaman meliputi jenis-jenis ancaman dan penggunaan ancaman pidana. Definisi ancaman terhadap kepentingan dan keamanan nasional dalam UU Intelijen juga menyertakan ancaman non-tradisional. Ancaman tidak hanya 
meliputi ancaman simetris (konvensional) yang berasal dari dalam maupun luar, namun juga ancaman non-konvensional yang bersifat global dan sulit untuk dikenali. Ancaman diklasifikasikan menjadi ancaman terhadap keamanan dalam negeri seperti separatisme, terorisme, spionase, sabotase, kekerasan politik, konflik horizontal, perang informasi, cyber war, dan ekonomi nasional, serta ancaman terhadap pertahanan yang meliputi perang tak terbatas, perang terbatas, konflik perbatasan, dan pelanggaran wilayah.

Tabel 4. Hasil Pengukuran Indikator Tata Kelola dalam UU No. 17 Tahun 2011

\begin{tabular}{|c|c|c|c|}
\hline $\begin{array}{c}\text { Pende } \\
\text { ka } \\
\text { Tan }\end{array}$ & $\begin{array}{l}\mathbf{N} \\
\mathbf{O}\end{array}$ & $\begin{array}{l}\text { Tata } \\
\text { Kelola }\end{array}$ & $\begin{array}{c}\text { Jumlah } \\
\text { kata }\end{array}$ \\
\hline \multirow{7}{*}{$\begin{array}{l}\text { Real } \\
\text { Isme }\end{array}$} & 1 & Kekuatan & 0 \\
\hline & 2 & Ancaman & 25 \\
\hline & 3 & $\begin{array}{c}\text { Kerahasiaa } \\
n\end{array}$ & 28 \\
\hline & 4 & $\begin{array}{c}\text { Kerjasama } \\
\text { (Lembaga } \\
\text { Intelijen) }\end{array}$ & 3 \\
\hline & 5 & Peraturan & 18 \\
\hline & & TOTAL & 74 \\
\hline & & $\begin{array}{c}\text { PERSENT } \\
\text { ASE }\end{array}$ & $62.18 \%$ \\
\hline \multirow{6}{*}{$\begin{array}{c}\text { Libera } \\
\text { l } \\
\text { Isme }\end{array}$} & 6 & Informasi & 17 \\
\hline & 7 & Kode etik & 10 \\
\hline & 8 & HAM & 7 \\
\hline & 9 & Kebebasan & 2 \\
\hline & & TOTAL & 36 \\
\hline & & $\begin{array}{c}\text { PERSENT } \\
\text { ASE }\end{array}$ & $30.25 \%$ \\
\hline
\end{tabular}

\begin{tabular}{|c|c|c|c|} 
& 10 & Konvensi & 0 \\
\cline { 2 - 4 } \multirow{4}{*}{$\begin{array}{c}\text { Konstr } \\
\text { uk } \\
\text { tivism } \\
\mathbf{e}\end{array}$} & 11 & $\begin{array}{c}\text { Nilai-nilai } \\
\text { agama }\end{array}$ & 3 \\
\cline { 2 - 4 } & 12 & $\begin{array}{c}\text { Nilai-nilai } \\
\text { demokrasi }\end{array}$ & 5 \\
\cline { 2 - 4 } & 13 & Moral & 1 \\
\cline { 2 - 4 } & & TOTAL & $\mathbf{9}$ \\
\hline TORSENT & ASE & $\mathbf{7 . 5 6 \%}$ \\
TELOL & TATA & $\mathbf{1 1 9}$ \\
\hline
\end{tabular}

Luaran yang hendak dicapai atau output yang terkandung dalam UU Intelijen juga menunjukkan cara pandang realis. Output yang hendak diupayakan lebih banyak berkaitan dengan kondisi keamanan nasional, hukum; sistem hukum, penghormatan dan kepastian terhadap hukum, ketertiban, dan stablitas. Sedangkan jumlah kata maupun frasa yang mengindikasikan output pendekatan liberalisme seperti terciptanya kesejahteraan, perdamaian, dan keadilan masih minim; hanya $20,90 \%$. 
Tabel 5. Hasil Pengukuran Indikator Output dalam UU No. 17 Tahun 2011

\begin{tabular}{|c|c|c|c|}
\hline $\begin{array}{c}\text { Pende } \\
\text { ka } \\
\text { Tan }\end{array}$ & $\begin{array}{l}\mathbf{N} \\
\mathbf{O}\end{array}$ & Output & $\underset{\text { kata }}{\text { Jumlah }}$ \\
\hline \multirow{6}{*}{$\begin{array}{l}\text { Reali } \\
\text { sme }\end{array}$} & 1 & Stabilitas & 1 \\
\hline & 2 & Keamanan & 35 \\
\hline & 3 & Ketertiban & 5 \\
\hline & 4 & Hukum & 12 \\
\hline & & TOTAL & 53 \\
\hline & & $\begin{array}{c}\text { PERSENTA } \\
\text { SE }\end{array}$ & $79.10 \%$ \\
\hline \multirow{6}{*}{$\begin{array}{l}\text { Liber } \\
\text { al } \\
\text { isme }\end{array}$} & 5 & Perdamaian & 3 \\
\hline & 6 & Kemerdekaan & 2 \\
\hline & 7 & $\begin{array}{c}\text { Keadilan } \\
\text { sosial }\end{array}$ & 3 \\
\hline & 8 & $\begin{array}{l}\text { Kesejahteraa } \\
\text { n umum }\end{array}$ & 6 \\
\hline & & TOTAL & 14 \\
\hline & & $\begin{array}{c}\text { PERSENTA } \\
\text { SE }\end{array}$ & $20.90 \%$ \\
\hline \multicolumn{3}{|c|}{ TOTAL OUTPUT } & 67 \\
\hline
\end{tabular}

PARADIGMA KEAMANAN

NASIONAL DAN TANTANGAN

BAGI INTELIJEN NEGARA

Keamanan nasional dalam UU Intelijen dimaknai sebagai kondisi bangsa dan negara yang dinamis, terjaminnya keselamatan, kedamaian, kesejahteraan warga negara, masyarakat dan terlindunginya kedaulatan, keutuhan wilayah, serta keberlangsungan pembangunan nasional. Keamanan nasional terdiri dari empat dimensi yang saling terkait satu dengan yang lainnya, yaitu keamanan manusia atau human security, keamanan dan ketertiban masyarakat, keamanan dalam negeri dan pertahanan (Undang-Undang Nomor 17 Tahun 2011 Tentang Intelijen, 2011). Pelaksanaan keamanan tentunya tidak dapat dipisahkan dari peran dan fungsi intelijen. Intelijen yang meliputi informasi, badan, maupun aktivitas, merupakan aspek yang sangat menentukan keselamatan negara dari berbagai ancaman, tantangan, hambatan, dan gangguan baik yang berasal dari dalam maupun luar negeri (Saronto \& Karwita, 2012).

Intelijen di Indonesia merupakan kristalisasi dari sejumlah pengalaman, baik berupa keberhasilan maupun kegagalan aktivitas intelijen di tanah air, serta kondisi sosial politik dan budaya bangsa (Saronto \& Karwita, 2012). Pada periode 19451949, aktor militer sepenuhnya mengendalikan proses pembentukan serta pelaksanaan operasi intelijen. Indonesia yang baru saja terlepas dari kolonialisme meletakkan ancaman yang berasal dari luar (asing) sebagai prioritas, sehingga era tersebut dikenal sebagai era Militerisasi Intelijen. Perubahan dari Militerisasi Intelijen menuju Intelijen Politik terjadi pada periode 1950-1959, ketika pemerintah harus menggerakkan militer untuk menghadapi ancaman dari dalam 
negeri. Pada periode Orde Baru, Indonesia yang dikenal sebagai Negara Intelijen mempolitisasi serta memiliterisasi lembaga-lembaga intelijen, sehingga personel intelijen dapat secara efektif masuk dalam berbagai lini kehidupan bernegara. Aktivitas intelijen pada periode Orde Baru bertujuan untuk menciptakan kontrol terhadap masyarakat. Individu maupun kelompok yang dianggap membahayakan bagi penguasa pada saat itu secara otomatis dianggap sebagai musuh negara. (Widjajanto \& Wardhani, 2008).

Reformasi pada tahun 1998 tidak hanya berdampak kepada perubahan dalam pemerintahan, namun juga kepada perubahan dalam lembaga serta aktivitas intelijen di Indonesia. Intelijen yang awalnya diidentikkan sebagai kepanjangan tangan penguasa, serta terlibat dalam sejumlah pelanggaran HAM, paska reformasi dituntut untuk bertindak profesional, obyektif, netral; tidak boleh terpengaruh oleh kepentingan pribadi, maupun golongan tertentu. Perubahan tersebut dipengaruhi oleh sejumlah faktor, yaitu adanya kebutuhan mendesak untuk mengembangkan intelijen untuk mengatasi ancaman yang semakin berkembang dan kompleks, kebutuhan untuk mengkonsolidasi proses demokrasi di Indonesia sehingga dibutuhkan lembaga intelijen yang akuntabel dan transparan, dan adanya pertimbangan hukum atau peraturan yang menghendaki adanya pengaturan yang lebih tegas terkait dengan intelijen (Widjajanto \& Wardhani, 2008). Badan Intelijen Negara kemudian resmi dibentuk pada era kepemimpinan Abdurrahman Wahid pada tahun 2000 (BIN, 2017). Meski BIN dibentuk dua tahun setelah reformasi, namun undang-undang tentang intelijen disahkan satu dekade setelah pembentukan BIN, setelah sebelumnya rancangan undangundang tentang intelijen telah diajukan sebanyak tiga kali pada tahun 2002, 2003, dan 2006 (Sandhiyudha, 2011).

\section{Perbandingan}

hasil pengukuran sejumlah indikator dengan pendekatan realisme, liberalisme, dan konstruktivisme, menunjukkan bahwa arah kebijakan keamanan dalam UU Intelijen didominasi oleh paradigma realisme. Keterlibatan aktor-aktor yang mayoritas merupakan aktor negara, kewenangan untuk melindungi, berkoordinasi dengan badan intelijen lain, mengawasi jalannya aktivitas intelijen, tata kelola dalam menghadapi ancaman, serta output yang menitikberatkan kepada 
terciptanya keamanan, terjaminnya hukum, dan ketertiban.

Tabel 6. Perbandingan Hasil Pengukuran

\begin{tabular}{|c|c|c|c|}
\hline $\begin{array}{c}\text { Indikat } \\
\text { or }\end{array}$ & $\begin{array}{l}\text { Real } \\
\text { isme }\end{array}$ & $\begin{array}{c}\text { Libe } \\
\text { ral } \\
\text { isme }\end{array}$ & $\begin{array}{l}\text { Konstrukti } \\
\text { visme }\end{array}$ \\
\hline Aktor & $\begin{array}{c}90.37 \\
\%\end{array}$ & $\begin{array}{c}0.74 \\
\%\end{array}$ & $8.89 \%$ \\
\hline $\begin{array}{c}\text { Otorita } \\
\text { s }\end{array}$ & $\begin{array}{c}93.46 \\
\%\end{array}$ & 0 & $6.54 \%$ \\
\hline $\begin{array}{c}\text { Anggar } \\
\text { an }\end{array}$ & $\begin{array}{c}100.0 \\
0 \%\end{array}$ & 0 & 0 \\
\hline $\begin{array}{c}\text { Tata } \\
\text { Kelola }\end{array}$ & $\begin{array}{c}62.18 \\
\%\end{array}$ & $\begin{array}{c}30.2 \\
5 \%\end{array}$ & $7.56 \%$ \\
\hline Output & $\begin{array}{c}79.10 \\
\%\end{array}$ & $\begin{array}{c}20.9 \\
0 \% \\
\end{array}$ & 0 \\
\hline
\end{tabular}

Semenjak era transisi serta reformasi dalam badan intelijen, Indonesia mulai menerapkan diferensiasi intelijen; pembentukan berbagai dinas intelijen yang dibentuk oleh negara yang demokratis, secara spesifik diarahkan untuk mengatasi suatu ancaman tertentu baik yang berasal dari dalam maupun luar negara. Namun, tidak dapat dipungkiri tugas dan fungsi intelijen sangat bergantung kepada persepsi pemimpin nasional mengenai keamanan nasional, sehingga badan serta pelaksanaan intelijen di Indonesia dulu hingga kini tetap didominasi oleh paradigma realisme. Bagaimanapun, intelijen merupakan lembaga yang secara langsung bertanggungjawab kepada presiden. Walaupun sejumlah gagasan paradigma liberalisme mengharuskan aktivitas intelijen untuk terbuka, transparan, obyektif, dan akuntabel. Namun, persoalan transparansi terkadang menimbulkan dilema sendiri bagi lembaga intelijen, terutama berkaitan dengan keamanan domestik. Lembaga beserta personel intelijen disatu sisi dituntut untuk tetap transparan, akuntabel, dan obyektif. Namun, di sisi lain intelijen juga dituntut untuk menjaga rahasia sesuai yang diatur dalam perundangundangan.

BIN kini menjadi koordinator bagi berbagai lembaga negara, seperti Badan Intelijen Strategis atau BAIS dalam TNI, Badan Intelijen Keamanan Polri atau Baintelkam Polri, Jaksa Agung Muda Bidang Intelijen atau JAM Intelijen dalam kejasaan, Badan Narkotika Nasional atau BNN, Direktorat Intelijen Keimigrasian, serta Intelijen BAKAMLA atau Badan Keamanan Laut. Walalupun pemerintah kini semakin memperkuat lembaga serta tugas dan fungsi intelijen negara. Namun, bukan berarti lembaga intelijen di Indonesia tidak memiliki kekurangan. Sesuai dengan yang termaktub dalam UU Intelijen Pasal 7, ruang lingkup intelijen negara terdiri dari intelijen dalam dan luar negeri, intelijen pertahanan dan atau 
militer, intelijen kepolisian, intelijen penegakan hukum, dan intelijen kementerian atau lembaga pemerintah non kementerian. Namun, hingga saat ini Indonesia belum memiliki intelijen pertahanan. Fungsi intelijen pertahanan kini diampu oleh Badan Intelijen Strategis atau yang dikenal dengan BAIS yang semula merupakan badan intelijen yang berada di bawah kewenangan Kementerian Pertahanan dan Keamanan atau Menhakam (kini Kemhan), namun kini terlepas dari Menhakam dan menjadi kewenangan militer; TNI.

Hal tersebut yang kemudian menggerakkan Kementerian Pertahanan, di bawah kepemimpinan Ryamizard Ryacudu pada tahun 2016 untuk mengajukan pembentukan badan intelijen pertahanan bagi Kemenhan (Lumbanrau $\&$ Kusumadewi, 2016). Kemhan belum memiliki instrumen intelijen yang bisa mengolah informasi adanya ancaman dari luar. Meski pada akhirnya usulan pembentukan intelijen pertahanan tersebut tidak disetujui oleh pemerintah. Intelijen strategi adalah lembaga intelijen yang bergerak di bidang strategi, saat ancaman perang sudah nyata, sedangkan intelijen pertahanan semestinya bertugas untuk membaca kemungkinan terjadinya ancaman melalui perang. Kedua fungsi tersebut selama ini memang dipegang oleh intelijen TNI. Hal tersebut di satu sisi menunjukkan bahwa pemerintah Indonesia kurang memprioritaskan persoalan pertahanan dibandingkan dengan persoalan keamanan, namun di sisi lain juga mengindikasikan bahwa lembagalembaga intelijen belum mampu untuk menjaga koordinasi serta mendukung satu sama lain.

Selain persoalan pembentukan intelijen pertahanan, otoritas BIN yang telah diatur dalam perundangundangan juga menjadi polemik. Sesuai dengan undang-undang, BIN memiliki otoritas untuk melakukan penyadapan, pemeriksaan aliran dana, dan penggalian informasi terhadap sasaran, dan dalam Pasal 34, BIN tidak memiliki kewenangan untuk melakukan penangkapan maupun penahanan. Namun dalam beberapa tahun terakhir, muncul wacana untuk merevisi otoritas BIN dengan menambahkan otoritas untuk melakukan penangkapan. Kepala BIN yang pada saat itu dijabat oleh Letjen TNI (Purn) Sutiyoso, dalam konferensi pers di kantor BIN pada tanggal $15 \quad$ Januari 2016 menyampaikan bahwa penanganan terorisme akan lebih efektif dengan 
melakukan revisi terhadap UndangUndang No. 15 tahun 2003 tentang Terorisme (BIN, 2016). Menteri Koordinator Bidang Politik Hukum dan Keamanan bahkan akan melakukan pengkajian terhadap revisi UU Intelijen (Utama, 2016). Namun, penambahan otoritas BIN untuk melakukan penangkapan tidak sesuai dengan KUHP. Selain itu, hal tersebut juga membuka kesempatan terjadinya penyalahgunaan wewenang dan pelanggaran HAM yang lebih luas, serta penangkapan terhadap 'terduga' tanpa adanya proses penyidikan terlebih dahulu.

Indonesia kini harus berhadapan dengan beragam persoalan keamanan nasional. BIN telah mengklasifikan ancaman menjadi delapan macam ancaman. Pertama, ancaman dengan menciptakan situasi yang tidak kondusif di pemerintahan dengan cara mempengaruhi kelompok tertentu, atau yang disebut dengan black operation. Kedua, penggiringan opini masyarakat atau psycho war melalui sejumlah berita; termasuk hoax, termasuk yang datang dari kelompok terorisme. Ketiga, perdagangan narkoba yang dilakukan oleh kartel internasional. Keempat, ancaman pemikiran atau ideologi yang anti terhadap Pancasila. Kelima, ancaman ekonomi seperti persaingan ekonomi yang tidak sehat, mafia pangan dan energi, serta tersebarnya produk impor palsu. Keenam, cyber and media war yang mengadu domba antara figur atau pemuka agama dengan pemerintah. Ketujuh, aktivitas intelijen yang dilakukan oleh negara lain melalui serangan virus komputer. Kedelapan, ancaman kelompok separatisme seperti Papua Barat serta Gerakan Aceh Merdeka (BIN, 2017).

Kasus penistaan agama sempat menggemparkan Indonesia pada tahun 2016. Menjelang pilkada DKI Jakarta, demonstrasi yang terjadi pada tanggal 4 September dan 2 Desember 2016, atau yang lebih dikenal dengan aksi 411 dan 212 juga didukung oleh Majelis Ulama Indonesia, atau MUI; sebuah lembaga Islam yang mewadahi sejumlah ormas Islam, para ulama'dan sekelompok cendekiawan muslim di Indonesia menuntut penegakan hukum atas terdakwa penistaan agama Basuki Cahya Purnama yang saat itu menjabat sebagai Gubernur DKI Jakarta. Pemberitaan media yang semakin gencar, kompetisi antar media baik cetak maupun elektronik, serta maraknya penggunaan sosial media memobilisasi sejumlah organisasi, partai, pergerakan atau harakah serta sejumlah kelompok Islam dalam 
berbagai kapasitas dan level yang menuntut penegakan hukum.

Namun, kasus tersebut hanyalah adalah awal bagi sejumlah konflik sosial-horizontal lainnya, atau bahkan vertikal. Penangkapan sejumlah ulama, serta pembubaran ormas yang dianggap anti-Pancasila dan keluarnya Perppu Nomor 2 tahun 2017 pada tanggal 10 Juli 2017 justru menambah polemik dan perdebatan yang terjadi di tengah-tengah masyarakat. Perang opini yang terjadi dalam pemberitaan sejumlah media menumbuhkan kecurigaan dan kemawasan pemerintah terhadap rakyat sipil dengan memberlakukan pengawasan yang ketat atas sejumlah aktivitas kelompok masyarakat. Selain konflik sosial dan perang opini, sejak tahun 2016 setidaknya dua kasus serangan bom terjadi di Indonesia, satu kali penembakan terhadap enam 'terduga' teroris tanpa proses interogasi, dan dua kali penembakan terhadap pelaku yang menyerang kepolisian. Inilah saat dimana intelijen bertugas untuk melakukan infiltrasi di tengah-tengah masyarakat. Namun, di sisi lain pengawasan pemerintah juga menyebabkan meluruhnya kepercayaan sebagian rakyat terhadap pemerintah.
Paradigma realisme juga terlihat dalam pengelolaan keamanan cyber. Dunia maya selama ini merupakan wilayah yang abu-abu yang bebas dari campur tangan dan pengawasan pemerintah. Siapa saja bebas untuk berpendapat, berekspresi, serta terjaga privasinya. Berdasarkan laporan dari Polda Metro Jaya, pada tahun 2016 setidaknya terdapat menangani 1.207 kasus cybercrime yang terjadi di Ibukota (Amelia, 2016). Kejahatan tersebut tidak hanya berupa pencurian dan penipuan atau fraud, namun juga penyebaran pesan negatif atau illegal content melalui website dan media sosial. Sejumlah website yang dikategorikan berbahaya bagi pemerintah diblokir, dan individu yang dianggap menebar kebencian dipolisikan. Kementerian Komunikasi dan Informasi atau Kemenkominfo juga sempat mewacanakan pembentukan Badan Siber Nasional, serta memberlakukan pemblokiran website telegram untuk mengantisipasi tersebarnya pesan bermuatan radikalisme yang kemudian juga menuai sentimen dari masyarakat bahwa pemerintah kini semakin bertindak represif. Sejumlah problem keamanan di atas menjelaskan turunnya indeks perdamaian di Indonesia pada tahun 2017, serta 
kenaikan skor political terror menjadi 3,5 .

Maka dari itu, untuk mengoptimalisasi tugas dan fungsi BIN dalam rangka menghadapi sejumlah potensi ancaman serta tantangan dalam keamanan nasional. Pemerintah kemudian mengeluarkan Peraturan Presiden atau Perpres Nomor 73 Tahun 2017 pada tanggal 27 Juli 2017. Perpres tersebut merupakan revisi atas Perpres Nomor 90 Tahun 2012 Tentang Badan Intelijen Negara (BIN). Perpres yang diajukan oleh Kementerian Hukum dan Hak Asasi Manusia dengan menambahkan Deputi Bidang Intelijen Siber (Cyber) dalam struktur Deputi BIN. Sesuai yang tertera dalam Perpres Pasal 25A, Deputi Bidang Intelijen Siber yang disebut Deputi VI, adalah pelaksana sebagian tugas dan fungsi BIN di bidang intelijen siber, yang berada di bawah dan bertanggung jawab kepada Kepala BIN. Deputi Bidang Komunikasi dan Informasi yang awalnya adalah Deputi VI kemudian berubah menjadi Deputi VII (Setkab RI, 2017).

Fungsi intelijen negara untuk melakukan pengawasan terhadap masyarakat juga semakin diperkuat dengan pembentukan Badan Intelijen Daerah atau BINDA serta pembentukan Koordinator Wilayah sesuai yang diatur dalam Perpres Nomor 73 tahun 2017 (Setkab RI, 2017). Pemerintah sebelumnya dinilai gagal dalam mendeteksi gerakan OPM, sehingga pada tanggal 7 Mei 2017, Panglima Tinggi Komando Nasional, Tentara Pembebasan Nasional Papua Barat (TPNPB) Jenderal Goliath Tabuni mendeklarasikan "perang" dengan militer Indonesia (Safari, 2017). Selain itu, sentimen masyarakat terkait dengan kasus penistaan agama juga dimanfaatkan oleh sejumlah oknum untuk mendeklarasikan gerakan separatisme Minahasa Merdeka (Komisi I DPR RI, 2017). Hal tersebut menunjukkan bahwa kapasitas lembaga intelijen Indonesia selama ini dianggap masih kurang dalam menghadapi ancaman keamanan yang terjadi di daerah. Pembentukan BINDA dan Koordinator Wilayah bisa jadi merupakan langkah awal yang menjembatani peran negara dengan masyarakat sipil dalam pelaksanaan intelijen.

\section{KESIMPULAN}

Analisa mengenai arah kebijakan pemerintah terkait dengan keamanan nasional dalam UU Nomor 17 Tahun 2011 Tentang Intelijen Negara, menunjukkan bahwa negara 
berperan sebagai main actor dalam pelaksanaan intelijen. Badan Intelijen Negara merupakan lembaga yang secara langsung berada di bawah tanggungjawab presiden dan menjadi koordinator bagi lembaga-lembaga intelijen. Otoritas untuk melakukan koordinasi, pengawasan jalannya aktivitas intelijen, serta tata kelola dalam menghadapi ancaman, dan output yang menitikberatkan kepada terwujudnya absence of the threat; keamanan, terjaminnya hukum, dan ketertiban merupakan indikasi dari paradigma realisme yang digunakan dalam pembuatan kebijakan.

$\begin{array}{cr}\text { Kelembagaan } & \text { intelijen } \\ \text { memang mengalami sejumlah }\end{array}$
perkembangan sejak awal kelahiran Indonesia hingga saat ini. Hal tersebut dapat dilihat dari diferensiasi lembaga intelijen, serta perubahan struktur, nilai, dan kewenangan lembaga intelijen paska terbentuknya BIN. Walaupun demikian, paradigma realisme tetap mendasari kebijakan intelijen di Indonesia, seperti persepsi mengenai ancaman terhadap keamanan yang meliputi ancaman dari dalam seperti operasi gelap, perang opini, terorisme, separatisme, ancaman terhadap ideologi maupun gerakan yang dianggap bertentangan dengan negara, serta ancaman dari luar; ancaman terhadap pertahanan negara. Paradigma realisme juga mendasari kebijakan pemerintah dalam membatasi arus informasi yang tersebar di dunia maya serta optimalisasi peran intelijen dalam bidang cyber.

\section{DAFTAR PUSTAKA}

Amelia, M. (2016, December 30). Kejahatan Cyber di Jakarta Sepanjang 2016 Mencapai 1.207 Kasus. Retrieved from Detik News: https://news.detik.com/berita/d3384545/kejahatan-cyber-dijakarta-sepanjang-2016mencapai-1207-kasus

Baylis, J. (2005). International and Global Security in the Post Cold War Era. In J. Baylis, \& S. Smith, The Globalization of World Politics (pp. 299-319). New York, United States of America: Oxford University Press.

BIN. (2016, January 15). Kepala BIN : Perlu Revisi UU Terorisme Terkait Kewenangan BIN. Retrieved from Badan Intelijen Negara: http://www.bin.go.id/nasional/deti 1/379/1/16/01/2016/kepala-bin-perlu-revisi-uu-terorisme-terkaitkewenangan-bin

BIN. (2017, July 17). Badan Intelijen Negara. Retrieved from Kepala BIN : Ulama Berperan Menyatukan Elemen Masyarakat dan Tangkal Ancaman: http://www.bin.go.id/nasional/deti 1/426/1/16/05/2017/kepala-bin-ulama-berperan-menyatukanelemen-masyarakat-dan-tangkalancaman 
BIN. (2017). Sejarah. Retrieved July 20, 2017, from Badan Intelijen Negara: http://www.bin.go.id/profil/sejara $\mathrm{h}$

Bradford, J. F. (2005). Naval War College Review. The Growing Prospects for Maritime Security Cooperation in Southeast Asia, 58(3).

Buzan, B. (2006). Will the 'global war on terrorism' be the new Cold War? International Affairs , 82(6), 1101-1118.

Eklof, S. (2006). Pirates in Paradise: A Modern History of Southeast Asia's Maritime Marauders . Copenhagen: NIAS Press.

Gartner, H., \& Cuthbertson, I. M. (2005). European Security and Transatlantic Relations after 9/11 and the Iraq War. New York: Palgrave.

IEP. (2017). Global Peace Index 2017. Sydney: The Institution for Economic and Peace. Retrieved from http://visionofhumanity.org/index es/global-peace-index/

Johnson, D., \& Valencia, M. (2005). Piracy in Southeast Asia: Status, Issues, and Responses. Singapore: ISEAS Publication.

Kemenhan, R. I. (2015). Buku Putih Pertahanan Indonesia. Jakarta: Kementerian Pertahanan Republik Indonesia.

Komisi I DPR RI. (2017, May 18). Pemerintah Diminta Sikapi Isu Gerakan Minahasa Merdeka. Retrieved from Dewan Perwakilah Rakyat Republik Indonesia: http://www.dpr.go.id/berita/detail/ id/16483/t/Pemerintah+Diminta+
Sikapi+Isu+Gerakan+Minahasa+ Merdeka

Kunarto. (1999). Intelijen: Pengertian dan Pemahamannya. Jakarta: Cipta Manunggal.

Lerner, K. L., \& Lerner, B. W. (2004). Encyclopedia of Espionage Intelligence and Security. United States of America: The Gale Group, Inc.

Liss, C. (2017). Piracy in Southeast Asia: Trends, Hotspots and Responses (1 ed.). New York, New York, United States: Routledge.

Liss, C., \& Biggs, T. (2016). Piracy in Southeast Asia: Trends, Hotspots, and Responses. New York: Routledge.

Lumbanrau, R. E., \& Kusumadewi, A. (2016, June 08). Menakar Urgensi Badan Intelijen Baru Buatan Kemhan. Retrieved from CNN Indonesia: https://www.cnnindonesia.com/na sional/20160608122252-20136666/menakar-urgensi-badanintelijen-baru-buatan-kemhan/

ReCAAP. (2006). About ReCAAP. Retrieved December 21, 2016, from ReCAAP.org: http://www.recaap.org/AboutReC AAPISC.aspx

ReCAAP. (2011). Annual Report 2011. Annual Report, ReCAAP, Singapore.

ReCAAP. (2012). Annual Report 2012. Annual Report, ReCAAP.

ReCAAP. (2013). Annual Report 2013. Annual Report, ReCAAP, Singapore.

ReCAAP. (2014). Annual Report 2014. Annual Report, ReCAAP, Singapore.

ReCAAP. (2015). Annual Report 2015. ReCAAP. Singapore: ReCAAP. 
ReCAAP. (2016). Commemorating a Decade of Cooperation. Regional Cooperation Agreement on Combating Piracy and Armed Robbery against Ships in Asia. ReCAAP.

Republik Indonesia. (1963). Penetapan Presiden No.11 Tahun 1963 Tentang Pemberantasan Kegiatan Subversi.

Republik Indonesia. (2011). UndangUndang Nomor 17 Tahun 2011 Tentang Intelijen.

Safari. (2017, May 09). Tantang RI Perang, Tindak Tegas Separatis $O P M$. Retrieved from Harian Terbit: http://nasional.harianterbit.com/n asional/2017/05/09/81055/0/25/T antang-RI-Perang-Tindak-TegasSeparatis-OPM

Sandhiyudha, A. (2011, June 20). Negara Intelijen vs Demokratisasi Intelijen. Retrieved from Republika: http://www.republika.co.id/berita/ nasional/opini/11/06/20/ln39lcnegara-intelijen-vs-demokratisasiintelijen

Saronto, Y. W., \& Karwita, J. (2012). Intelijen. Bandung: Prodi D-III Kepolisian Fisip Universitas Langlangbuana.

Setkab RI. (2017, July 28). Perpres Direvisi, BIN Kini Punya Deputi Bidang Intelijen Siber. Retrieved from Sekretaris Kabinet Republik Indonesia: http://setkab.go.id/perpresdirevisi-bin-kini-punya-deputibidang-intelijen-siber/
Storey, I. (2009). Maritime Security in Southeast Asia: Two Cheers for Regional Cooperation. Southeast Asian Affairs, 2009.

Sukma, R. (2003). KEAMANAN

INTERNASIONAL PASCA 11

SEPTEMBER: TERORISME, HEGEMONI AS DAN IMPLIKASI REGIONAL. SEMINAR PEMBANGUNAN HUKUM NASIONAL VIII TEMA PENEGAKAN HUKUM DALAM ERA PEMBANGUNAN BERKELANJUTAN.

DENPASAR: BADAN PEMBINAN HUKUM NASIONAL DEPARTEMEN KEHAKIMAN DAN HAK ASASI MANUSIA RI.

Utama, A. (2016, January 08). Menteri Luhut Buka Peluang Revisi UU Intelijen. Retrieved from CNN Indonesia: https://www.cnnindonesia.com/po litik/20160118155530-32105095/menteri-luhut-bukapeluang-revisi-uu-intelijen/

Weatherbee, D. E. (2010). International Relations in Southeast Asia: The Struggle for Autonomy (2nd Edition ed.). Pasir Panjang, Singapore, Singapore: ISEAS Publishing.

Widjajanto, A., \& Wardhani, A. (2008). Hubungan Intelijen Negara 1945 2004. Jakarta: Pacivis University of Indonesia.

William, P. D. (2008). Security Studies: an Introduction. Oxon, United Kingdom: Routledge. 